\title{
Visual Communication Board for Communication Compromised Patients
}

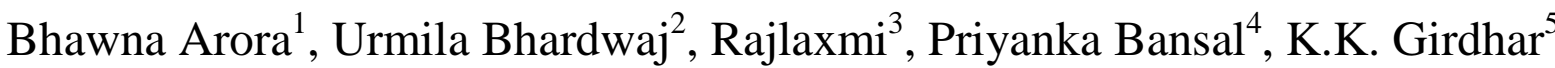 \\ ${ }^{1}$ Nursing officer, Deen Dayal Upadhyay Hospital, Hari Nagar, New Delhi, India \\ ${ }^{2}$ Associate Professor, Rufaida College of Nursing, Jamia Hamdard, New Delhi, India \\ ${ }^{3}$ Tutor, Rufaida College of Nursing, Jamia Hamdard, New Delhi, India \\ ${ }^{4}$ Tutor, Rufaida College of Nursing, Jamia Hamdard, New Delhi, India \\ ${ }^{5}$ Consultant and Head, Department of Anaesthesiology and Intensive Care, VMMC and SJH, New Delhi, India
}

\begin{abstract}
Background

Human speech is the wonderful gift given to human being by God for communicating their ideas, needs and feelings. But an inability to speak, no matter temporary can be catastrophic for the patients in tertiary care. Some patients in tertiary care units may be communication compromised due to various reasons. A quasi experimental study was conducted to evaluate the effectiveness of visual communication board on satisfaction regarding communication needs of communication compromised patients in selected hospitals of Delhi.
\end{abstract}

\section{Objectives}

Objectives of the study were 1) To assess and compare the level of satisfaction regarding communication needs of communication compromised patients in both experimental and control group after administration of visual communication board in experimental group and traditional methods in control group 2) To establish association between the level of satisfaction regarding communication needs of communication compromised patients in both experimental and control group with selected variables after administration of visual communication board in experimental group and traditional methods in control group.

Methodology

The quasi experimental research with posttest only control group design was used. Sample comprised of total 60 communication compromised patients (30 experimental and 30 control group) selected by purposive sampling. Patient data record sheet and Satisfaction scale were tools used for data collection.

Results

In experimental group maximum of study subjects i.e. 13(43.33\%) were satisfied followed by 9(30\%) study subjects completely satisfied and only 2(6.67\%) were unsatisfied. In control group maximum of study subjects i.e. $11(36.67 \%)$ were completely unsatisfied followed by 10(33.33\%) study subjects unsatisfied and only $2(6.67 \%)$ were satisfied. The level of satisfaction perceived by study subjects in experimental group was significantly higher than the control group.

Conclusion

The visual communication board improved the level of satisfaction of communication compromised patients \& thus can be used to cater the communication needs of communication compromised patients.

Key words: Visual Communication Board, Communication Compromised Patients and Communication Needs

\section{Background}

\section{Please listen to me, I want to say something. \\ I am also a human being; I want to communicate my needs. \\ (Expressed by a communication compromised patient)}

Communication is a vital component in serving needs of patients in intensive care units where patients can have impaired communication abilities due to their communication compromised status. Patient's health is influenced by patient's abilities to communicate effectively. ${ }^{1}$ Patient's whose informed consent is taken for care and treatment participate well in care aspects. ${ }^{2}$

Some patients in tertiary care units may be communication compromised due to various reasons. Common reasons of compromised communication in tertiary care units are endotracheal intubation, tracheostomy, stroke and head/neck surgery. Intubated patients can't speak because of endotracheal tube being passed through vocal cords. ${ }^{3}$ Tracheostomy patients might not be able to create voice while tracheostomy tube is in place, as air is no longer passing through the vocal cords. ${ }^{4}$ In stroke patients, aphasia is a condition in which 
patient may not be able to generate speech or comprehend words to develop messages..$^{5-6}$ In head and neck surgery units, oropharyngeal and laryngeal cancer, postoperative cases and post radiotheraphy patients are unable to speak because of pathological conditions and surgical interventions. ${ }^{7}$

Nurses and health care professionals face many problems in communicating with communication compromised patients. They may feel disappointed with inability to understand patient's messages for fulfilling their basic needs which may result in the patient becoming angry or anxious and ultimately abandoning the attempt to communicate. ${ }^{8,9,10}$

For such patients nonverbal methods can be used but adequate communication skills, knowledge and technologies are required to support communication and enhance response from patient. ${ }^{8-9} \mathrm{~A}$ number of methods are available to facilitate communication in these patient populations. These include the use of verbal and nonverbal language and variety of devices to assist the short term and long-term ventilator-assisted patients. Simple devices, traditional methods available to overcome interference in communication include writing with pen and paper, pointing and hand gestures, facial expressions, lip reading or mouthing of words, use of letter board (magnetic boards with plastic letters), erase and write board (magic slate), head nods, coded eye blinks and flash cards etc. High tech alternative augmentative devices available to overcome interference in communication include pictorial, written vidatak board, vidatalkiphone application, chat books, electronic communication board, eye gaze displays, electrolarynges, speech generating devices, digitalized recording systems etc. ${ }^{4,11-13}$

In India, we merely use any communication board to communicate effectively with the patients to adapt positively with the environment, provide better care and attain better outcomes. Lack of access to appropriate augmentative and alternative communication strategies in tertiary care settings increases the amount of time and effort spent on communication, leading to frustration for both patients and health care providers. Also communication board can be a suitable method for communicating with communication compromised patients in Indian settings as it is easily accessible, easy to handle and economic tool if found effective for such patients. Hence the researcher felt need to assess the effectiveness of visual communication board on satisfaction regarding communication needs of communication compromised patients.

\section{Review Of Literature}

The literature review of this study has been organized in the following headings:

1. Review of literature related to communication of patients in nursing practice

2. Review of literature related to devices used for communication

\section{Review of literature related to communication of patients in nursing practice}

Wang Y et al. ${ }^{14}$ analyzed major complaints from patients during mechanical ventilation after cardiac surgery and identified the most common complaints to reduce adverse psychologic responses. The factors affecting comfort included dry mouth, thirst, tracheal intubation, aspiration of sputum, communication barriers, limited mobility, fear/anxiety, patient-ventilator dyssynchrony, and poor environmental conditions. Patients considered mechanical ventilation to be the worst part of their hospitalization.

Baumgarten $\mathrm{M}$ et al. ${ }^{15}$ did a study to gather and synthesize interpreted knowledge from qualitative studies about patients' experiences of being mechanically ventilated in an ICU. Fifteen abstracted findings appeared from the metasynthesis and led to the synthesised finding: 'Being dependent on health professionals, without being able to communicate, causes experiences with anxiety, fear and loneliness.

Magnus VS et al. ${ }^{16}$ investigated staff and patient perceptions and experiences of communication within ICUs and results of study showed that for members of the multidisciplinary team breakdown in communication with patients may be frustrating and related to a limited knowledge of strategies and resources to facilitate communication.

\section{Review of literature related to devices used for communication}

Patak L et al. ${ }^{10}$ studied the effect of communication board on perceived level of frustration in patients receiving mechanical ventilation and found that if a communication board, if used patiently during mechanical ventilation, has been shown to alleviate frustration with communication.

Rajan $\mathrm{R}^{17}$ interviewed 30 post $\mathrm{CABG}$ extubated patients and collected data pertaining to their needs and problems when they were on mechanical ventilation after CABG. The means of communication used by majority patients during the period of mechanical ventilation were gestures $(90 \%)$ followed by head nods (53.33\%), use of pen and paper (6.67\%) and eye blinks (3.33\%). Patients reported that pain and need to change position were the major needs they wanted to communicate. The other problems reported were dry mouth, thirst, inability to sleep, feeling itchy and chocking sensation. 
Finke EH et al. ${ }^{8}$ conducted a systematic review on research regarding communication between nurses and patients with complex communication needs $(\mathrm{CCN})$. Nurses and patients have reported concern and frustration when communication is not adequate. Further, specific strategies (i.e., using AAC) that nurses can use to improve and facilitate communication with patients with $\mathrm{CCN}$ were provided.

Happ MB et al. ${ }^{7}$ conducted a literature review on communication needs, methods, and perceived voice quality in adult patients following head and neck surgery. This review showed that the communication needs, communication methods, and perception of voice quality among patients with head and neck cancer have been ignored during the in-hospital period.

\section{Methodology}

Conceptual framework adopted for the study was based on transactional theory of communication. The quasi experimental researchwith post test only control group designwas used for the study. Sample comprised of total 60 communication compromised patients (30 experimental and 30 control group) selected by purposive sampling from Safdarjung Hospital, New Delhi and Sanjay Gandhi Memorial Hospital, New Delhi after taking prior approval. Ethical clearance was taken for the study from IEC, JamiaHamdard and IEC, Safdarjung Hospital.Pair matching of participants was done on key variables to make group more comparable. The experimental group was exposed to the visual communication board (for 3 days) as an intervention to meet their communication needs.

Visual Communication Board was developed by extensive review of research and non- research literature to develop the needed items, consultation with experts in the nursing, medical and paramedical field and then formulation of the items (pictures / icons) according to communication needs of communication compromised patients.

Patient data record sheet and Satisfaction scale developed by researcher were used for data collection.

- Patient data record sheet related to demographic variables consist of age, sex, educational status, duration of compromised communication and reason of compromised communication.

- $\quad$ Satisfaction scale based on 5 point likert Scale.

Scoring for satisfaction scale was scored on a five point scale ranging from 1-5 about specific mode of communication. Score 1 was given if the patient was not at all satisfied. A score of 2 was given if patient was slightly satisfied. Score of 3 was given if the patient was having neutral response. Score of 4 was given if the patient was very satisfied. And score of 5 was given if patient was completely satisfied.

Content validity of patient data record sheet related todemographic variables, satisfaction scale and visual communication board was established by experts from the field of Nursing, Anaesthesia, Surgery, ENT, Speech and Audiology. The reliability of the tool was checked using interobserver reliability and percentage of agreement between assigned score was $0.90(90 \%)$.

All the items in the tool were coded and transferred to the master data sheet. Then analysis of data was done using descriptive and inferential statistics using SPSS version 21. The level of significance was kept at 0.05 level.

The data rendered the following results:

\section{Results}

\section{I) Findings related to Demographic Variables of Communication Compromised Patients in experimental and control group}

Table 1Frequency and Percentage distribution of Demographic Variablesof Experimental group and Control group and their relationship

$$
\mathrm{n}_{1}+\mathrm{n}_{2}=60
$$

\begin{tabular}{|c|c|c|c|c|c|c|c|}
\hline \multirow[t]{2}{*}{ S.No. } & \multirow[t]{2}{*}{ Demographic Variables } & \multicolumn{2}{|c|}{$\begin{array}{c}\text { Experimental Group } \\
\mathrm{n}_{1}=30\end{array}$} & \multicolumn{2}{|c|}{$\begin{array}{c}\text { Control Group } \\
\mathrm{n}_{2}=30\end{array}$} & \multirow[t]{2}{*}{ Test Applied } & \multirow{2}{*}{$\begin{array}{c}\mathrm{p} \\
\text { Value }\end{array}$} \\
\hline & & Frequency & Percentage & Frequency & Percentage & & \\
\hline
\end{tabular}


Visual Communication Board for Communication Compromised Patients

\begin{tabular}{|c|c|c|c|c|c|c|c|}
\hline 1. & $\begin{array}{c}\text { Age (in years) } \\
18-35 \\
36-50 \\
51-65 \\
66 \text { and above }\end{array}$ & $\begin{array}{c}13 \\
8 \\
8 \\
1\end{array}$ & $\begin{array}{c}43.33 \\
26.67 \\
26.67 \\
3.33\end{array}$ & $\begin{array}{l}11 \\
9 \\
8 \\
2\end{array}$ & $\begin{array}{c}36.67 \\
30 \\
26.67 \\
6.67\end{array}$ & $\begin{array}{c}\text { Fisher's } \\
\text { Exact }\end{array}$ & 0.91 \\
\hline 2. & $\begin{array}{c}\text { Sex } \\
\text { Male } \\
\text { Female }\end{array}$ & $\begin{array}{l}18 \\
12\end{array}$ & $\begin{array}{l}60 \\
40\end{array}$ & $\begin{array}{l}20 \\
10\end{array}$ & $\begin{array}{l}66.67 \\
33.33\end{array}$ & Chi-Square & 0.59 \\
\hline 3. & $\begin{array}{c}\text { Educational Status } \\
\text { Illiterate } \\
\text { Can read and write } \\
\text { Secondary } \\
\text { Senior Secondary } \\
\text { Graduate and above }\end{array}$ & $\begin{array}{l}7 \\
8 \\
3 \\
9 \\
3\end{array}$ & $\begin{array}{c}23.33 \\
26.67 \\
10 \\
30 \\
10\end{array}$ & $\begin{array}{l}8 \\
5 \\
6 \\
7 \\
4\end{array}$ & $\begin{array}{c}26.67 \\
16.67 \\
20 \\
23.33 \\
13.33\end{array}$ & $\begin{array}{c}\text { Fisher's } \\
\text { Exact }\end{array}$ & 0.71 \\
\hline 4. & $\begin{array}{c}\text { Duration of } \\
\text { Compromised } \\
\text { Communication } \\
\text { Less than } 3 \text { days } \\
3 \text { days } \\
\text { More than } 3 \text { days }\end{array}$ & $\begin{array}{c}8 \\
5 \\
17\end{array}$ & $\begin{array}{l}26.67 \\
16.67 \\
56.67\end{array}$ & $\begin{array}{c}10 \\
4 \\
16\end{array}$ & $\begin{array}{l}33.33 \\
13.33 \\
53.33\end{array}$ & $\begin{array}{c}\text { Fisher's } \\
\text { Exact }\end{array}$ & 0.83 \\
\hline 5. & $\begin{array}{c}\text { Reason of } \\
\text { Compromised } \\
\text { Communication } \\
\text { Endotracheal tube } \\
\text { Tracheostomy } \\
\text { Head and Neck Surgery } \\
\text { Stroke }\end{array}$ & $\begin{array}{c}16 \\
9 \\
5 \\
0\end{array}$ & $\begin{array}{c}53.33 \\
30 \\
16.67 \\
0.00\end{array}$ & $\begin{array}{c}14 \\
11 \\
5 \\
0\end{array}$ & $\begin{array}{c}46.67 \\
36.67 \\
16.67 \\
0.00\end{array}$ & $\begin{array}{c}\text { Fisher's } \\
\text { Exact }\end{array}$ & 0.85 \\
\hline
\end{tabular}

$\mathrm{p}$ value significant at 0.05 level of significance

The data in table 1 showed that there was no statistical significant difference found between demographic variables of experimental and control group at 0.05 level of significance. Hence it can be said that both groups were homogenous.

\section{II) Findings related to Level of Satisfaction perceived by Communication Compromised Patients in experimental and control group}

Table 2Level of Satisfaction perceived by Communication Compromised Patientsin experimental and control group

\begin{tabular}{|c|c|c|c|c|c|c|c|}
\hline \multirow{3}{*}{ S.No. } & \multirow{3}{*}{ Level of Satisfaction } & \multirow{2}{*}{\multicolumn{2}{|c|}{$\begin{array}{c}\text { Experimental Group } \\
\mathrm{n}_{1}=30\end{array}$}} & \multirow{2}{*}{\multicolumn{2}{|c|}{$\begin{array}{c}\text { Control Group } \\
\mathrm{n}_{2}=30\end{array}$}} & \multirow{3}{*}{$\begin{array}{c}\text { Fisher's } \\
\text { Exact Test } \\
\text { Value }\end{array}$} & \multirow{3}{*}{$\mathrm{p}$ value } \\
\hline & & & & & & & \\
\hline & & Frequency & Percentage & Frequency & Percentage & & \\
\hline 1. & CompletelySatisfied (5) & 9 & 30 & 0 & 0.00 & \multirow{5}{*}{33.48} & \multirow{5}{*}{$0.00 *$} \\
\hline 2. & Satisfied(4) & 13 & 43.33 & 2 & 6.67 & & \\
\hline 3. & Neutral (3) & 6 & 20 & 7 & 23.33 & & \\
\hline 4. & Unsatisfied(2) & 2 & 6.67 & 10 & 33.33 & & \\
\hline 5. & Completely Unsatisfied(1) & 0 & 0.00 & 11 & 36.67 & & \\
\hline
\end{tabular}

*p value significant at 0.05 level of significance

Findings from table2 revealed that in experimental group maximum of study subjects i.e. $13(43.33 \%)$ were satisfied followed by $9(30 \%)$ study subjects completely satisfied and 6(20\%) study subjects had neutral response. In control group maximum of study subject i.e.11 (36.67\%) were completely unsatisfied followed by $10(33.33 \%)$ study subjects unsatisfied and 7(23.33\%) study subjects had neutral response. 
It is seen that the level of satisfaction perceived by study subjects in experimental group was significantly higher than the control group at 0.05 level of significance. Thus the null hypothesis is rejected and the research hypothesis is accepted.

III) Findings related to establishment of association between Level of Satisfaction perceived by Communication Compromised Patients in experimental and control group with selected Demographic Variables

Table 3Association between Level of Satisfaction perceived by Communication Compromised Patients in Experimental group with selected Demographic Variables by Fisher's Exact Test

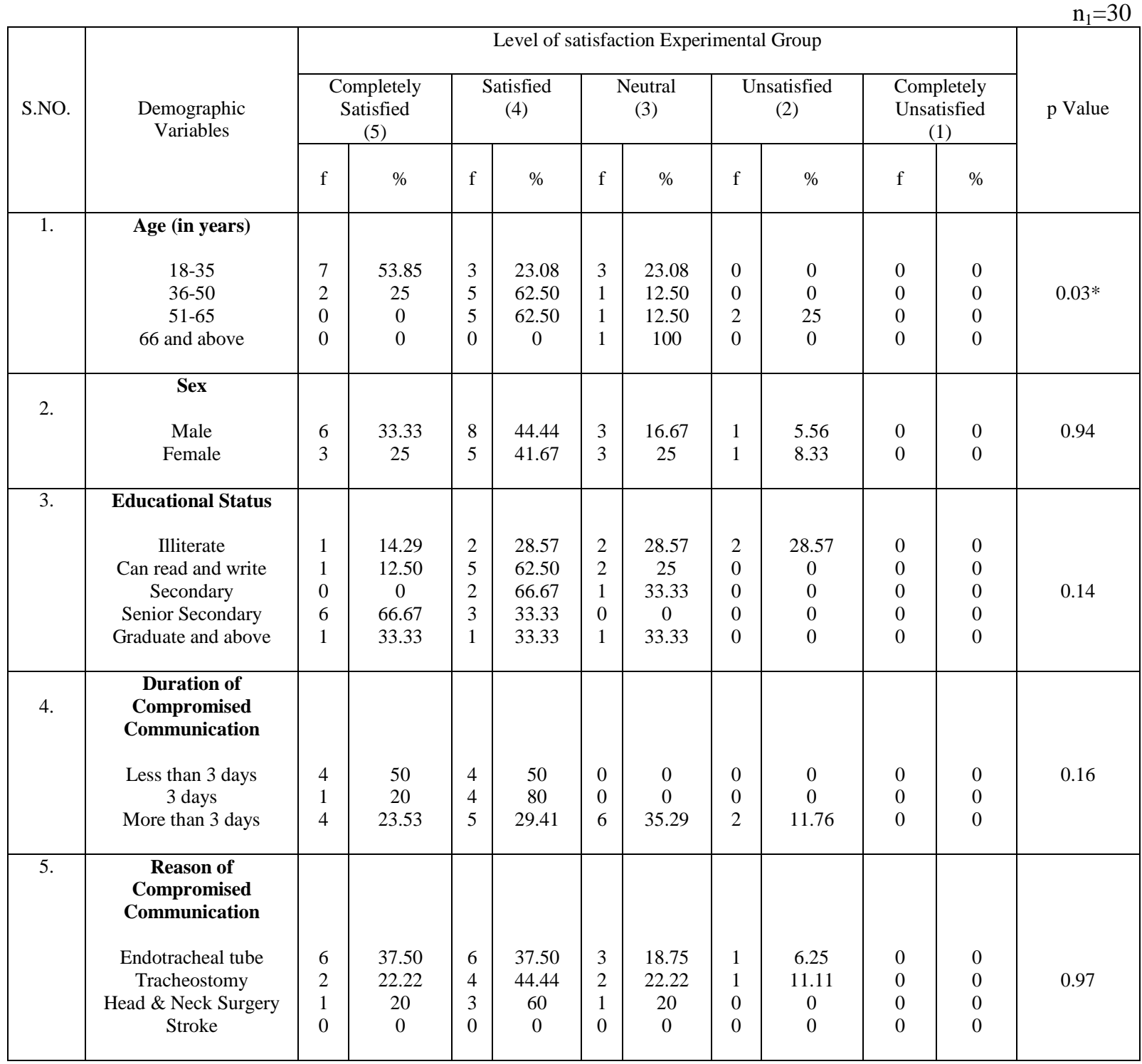

*p value significant at 0.05 level of significance

The data in table 3 showed that in experimental group there is a statistically significant association between the level of satisfaction perceived by study subjects with age at 0.05 level of significance.

Table 4Association between Level of Satisfaction perceived by Communication Compromised Patients in Control group with selected Demographic Variables by Fisher's Exact Test

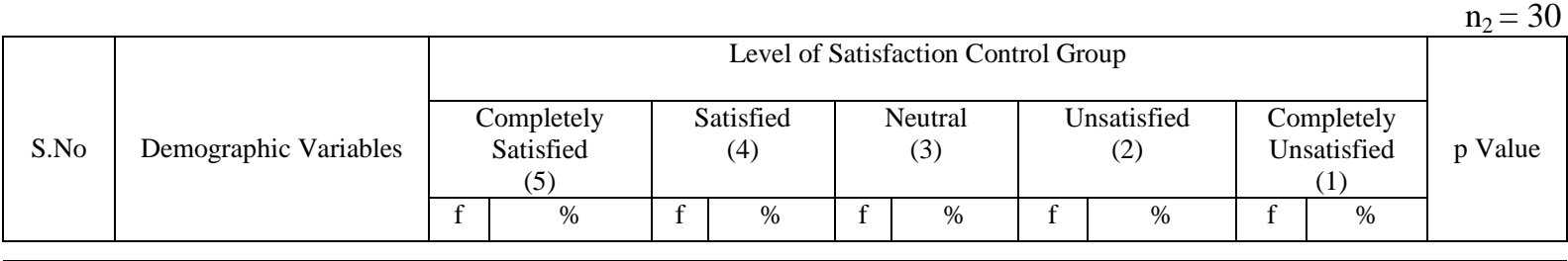




\begin{tabular}{|c|c|c|c|c|c|c|c|c|c|c|c|c|}
\hline & & & & & & & & & & & & \\
\hline 1. & $\begin{array}{c}\text { Age (in years) } \\
\text { 18-35 } \\
36-50 \\
51-65 \\
66 \text { and above }\end{array}$ & $\begin{array}{l}0 \\
0 \\
0 \\
0\end{array}$ & $\begin{array}{l}0 \\
0 \\
0 \\
0\end{array}$ & $\begin{array}{l}2 \\
0 \\
0 \\
0\end{array}$ & $\begin{array}{c}18.18 \\
0 \\
0 \\
0\end{array}$ & $\begin{array}{l}2 \\
2 \\
3 \\
0\end{array}$ & $\begin{array}{c}18.18 \\
22.22 \\
37.50 \\
0\end{array}$ & $\begin{array}{l}4 \\
3 \\
3 \\
0\end{array}$ & $\begin{array}{c}36.36 \\
33.33 \\
37.50 \\
0\end{array}$ & $\begin{array}{l}3 \\
4 \\
2 \\
2\end{array}$ & $\begin{array}{c}27.27 \\
44.44 \\
25 \\
100\end{array}$ & 0.76 \\
\hline 2. & $\begin{array}{c}\text { Sex } \\
\text { Male } \\
\text { Female }\end{array}$ & $\begin{array}{l}0 \\
0\end{array}$ & $\begin{array}{l}0 \\
0\end{array}$ & $\begin{array}{l}1 \\
1\end{array}$ & $\begin{array}{c}5 \\
10\end{array}$ & $\begin{array}{l}7 \\
0\end{array}$ & $\begin{array}{c}35 \\
0\end{array}$ & $\begin{array}{l}5 \\
5\end{array}$ & $\begin{array}{l}25 \\
50\end{array}$ & $\begin{array}{l}7 \\
4\end{array}$ & $\begin{array}{l}35 \\
40\end{array}$ & 0.13 \\
\hline 3. & $\begin{array}{c}\text { Educational Status } \\
\text { Illiterate } \\
\text { Can read and write } \\
\text { Secondary } \\
\text { Senior Secondary } \\
\text { Graduate and above }\end{array}$ & $\begin{array}{l}0 \\
0 \\
0 \\
0 \\
0\end{array}$ & $\begin{array}{l}0 \\
0 \\
0 \\
0 \\
0\end{array}$ & $\begin{array}{l}0 \\
0 \\
0 \\
1 \\
1\end{array}$ & $\begin{array}{c}0 \\
0 \\
0 \\
14.29 \\
25\end{array}$ & $\begin{array}{l}0 \\
2 \\
3 \\
0 \\
2\end{array}$ & $\begin{array}{c}0 \\
40 \\
50 \\
0 \\
50\end{array}$ & $\begin{array}{l}4 \\
3 \\
1 \\
1 \\
1\end{array}$ & $\begin{array}{c}50 \\
60 \\
16.67 \\
14.29 \\
25\end{array}$ & $\begin{array}{l}4 \\
0 \\
2 \\
5 \\
0\end{array}$ & $\begin{array}{c}50 \\
0 \\
33.33 \\
71.43 \\
0\end{array}$ & $0.02 *$ \\
\hline 4. & $\begin{array}{c}\text { Duration of } \\
\text { Compromised } \\
\text { Communication } \\
\\
\text { Less than } 3 \text { days } \\
3 \text { days } \\
\text { More than } 3 \text { days }\end{array}$ & $\begin{array}{l}0 \\
0 \\
0\end{array}$ & $\begin{array}{l}0 \\
0 \\
0\end{array}$ & $\begin{array}{l}0 \\
0 \\
2\end{array}$ & $\begin{array}{c}0 \\
0 \\
12.25\end{array}$ & $\begin{array}{l}4 \\
1 \\
2\end{array}$ & $\begin{array}{c}40 \\
25 \\
12.25\end{array}$ & $\begin{array}{l}3 \\
2 \\
5\end{array}$ & $\begin{array}{c}30 \\
50 \\
31.25\end{array}$ & $\begin{array}{l}3 \\
1 \\
7\end{array}$ & $\begin{array}{c}30 \\
25 \\
43.75\end{array}$ & 0.70 \\
\hline 5. & $\begin{array}{c}\text { Reason of } \\
\text { Compromised } \\
\text { Communication } \\
\text { Endotracheal tube } \\
\text { Tracheostomy } \\
\text { Head and Neck Surgery } \\
\text { Stroke }\end{array}$ & $\begin{array}{l}0 \\
0 \\
0 \\
0\end{array}$ & $\begin{array}{l}0 \\
0 \\
0 \\
0\end{array}$ & $\begin{array}{l}0 \\
2 \\
0 \\
0\end{array}$ & $\begin{array}{l}0 \\
18.18 \\
0 \\
0\end{array}$ & $\begin{array}{l}3 \\
2 \\
2 \\
0\end{array}$ & $\begin{array}{l}21.43 \\
18.18 \\
40 \\
0\end{array}$ & $\begin{array}{l}5 \\
3 \\
2 \\
0\end{array}$ & $\begin{array}{l}35.71 \\
27.27 \\
40 \\
0\end{array}$ & $\begin{array}{l}6 \\
4 \\
1 \\
0\end{array}$ & $\begin{array}{l}42.86 \\
36.36 \\
20 \\
0\end{array}$ & 0.73 \\
\hline
\end{tabular}

*p value significant at 0.05 level of significance

Data in table 4 depicts that in control group there is statistically significant association between the level of satisfaction perceived by study subjects with educational status at 0.05 level of significance.

\section{Discussion}

Present study revealed that the maximum of study subjects i.e $13(43.33 \%)$ in experimental group were satisfied and the level of satisfaction perceived by communication compromised study subjects in experimental group was significantly higher than the control group. Findings of the present study is consistent with the study done by El-Soussi AH et al. ${ }^{9}$ which shows the majority of study subjects in the study group (63.3\%) evaluated communication methods used by the researcher as "extremely helpful" and indicated that alternative communication methods can improve the level of satisfaction.

The present study revealed that the maximum of study subjects $11(36.67 \%)$ in control group were completely unsatisfied. The findings of present study is in line with a study conducted by Happ MB et al. ${ }^{18}$ who found that the study subjects rated $40 \%$ of the communication sessions with nurses as somewhat difficult to extremely difficult with little to no use of assistive communication strategies. Findings of the present study is also in line with the study conducted by Guttormson JL et al. ${ }^{19}$ on mechanically ventilated study subjects to describe the patient experience of communication during mechanical ventilation. According to this study inability to communicate needs was associated with helplessness. Ineffective communication impacted negatively on satisfaction with care.

Present study revealed that there is statistically significant association between the level of satisfaction perceived by communication compromised study subjects with age in experimental group and educational status in control group but there is no significant difference with other selected variables. Findings of the present study are not in line with the findings of qualitative study conducted byFlinterud SI et al. ${ }^{20}$ Their themes were of three categories. The category 'Emotionally challenging' shows that study subjects struggled initially. With time, their coping improved, as revealed in the category 'The experience changes with time.'

Subjective feeling of researcher is that any communication method can be only effective with intention of communicator and recipient to communicate. Also alternative augmentative communication devices can be 
very helpful, if the communicator possesses communication skills and technical skills to use these devices. With passage of time individual needs of patients changes so visual communication board needs revision.

\section{Conclusion}

Maximum of study subjects in experimental group were satisfied with visual communication Board and also the level of satisfaction perceived by study subjects in experimental group was significantly higher than the control group. Hence visual communication board was found to be effective in increasing the level of satisfaction of communication compromised patients.

Nurses and other health care professionals need to have access to communication devices, tools and technologies at the same time; they should be equipped with necessary knowledge and skills to use these devices for optimum impact.Regular in service education programmes should be conducted to update the knowledge of nurses and other health care professionals regarding usage of communication devices and skills to use them. There is high need for extended research in the field for development of various communication devices for communication compromised patients.

\section{References}

[1] K Ruth M, Patak L, Wilson-Stronks A, Costello J, Henneman E A. Communication in the ICU [Internet]. Advance Health Care Network; 2008: 1-2

[2] KapoorB. Need for Communication. Communication in Nursing. New Delhi: IGNOU; 2011 Dec: 8

[3] Happ MB. Communicating with Mechanically Ventilated Patients: State of Science. Advanced Practice in Acute Critical Care. 2001May;12(2): 247-258

[4] St. George's University Hospitals. Communication [Internet]. London; 2014 [updated 2014 May; cited 2016 Jan 16]. Available from: http://www.stgeorges.nhs.uk/gps_and_clinicians/clinical_resources/tracheostomy_guidelines/ communication/

[5] Sheldon LK. Communication for Nurses: Talking with Patients. $2^{\text {nd }}$ Edition. New Delhi : Jones \&Barlett India Private Limited; 2011

[6] Sorensen, Braendgaard R, Uhrenfeldt, Lisbeth. Stroke Survivors' Experiences of Communication with Healthcare Providers in Long-Term Care Settings: A Systemic Review Protocol. JBI Database of Systemic Reviews and Implementation Reports. 2016; 14(9): 85-92

[7] Happ MB, Roesch T, Kagan SH. Communication Needs, Methods, and Perceived Voice Quality Following Head and Neck Surgery: A literature Review. Cancer Nursing.2004 Jan-Feb; 27(1): 1-9

[8] Finke EH, Light J, Kitko L. A Systematic Review of the Effectiveness of Nurse Communication with Patients with Complex Communication Needs with a Focus on the Use of Augmentative and Alternative Communication. Journal of Clinical Nursing. 2008 Aug; 17(16): 2102-2115

[9] El-Soussi AH, Elshafey MM, Othman SY, Abd-Elkader FA. Augmented Alternative Communication Methods in Intubated COPD Patients: Does it Make Difference. Egyptian Journal of Chest Diseases and Tuberculosis. 2014 Aug; 64: 21-28

[10] Patak L, Gawlinski A, Fung NI, Doering L, Berg J. Communication Boards in Critical Care: Patients' Views. Applied Nursing Research. 2006;19(4): 182-90

[11] Grossbach I, Stranberg S, Chlan L. Promoting Effective Communication for Patients Receiving Mechanical Ventilation. Critical Care Nurse. 2011Jun; 31(3):46-60

[12] Happ MB, Tuite P, Dobbin K, DiVirgilio-Thomas D, Kitutu J. "Communication Ability, Method, and Content among Nonspeaking Non surviving Patients Treated with Mechanical Ventilation in the Intensive Care Unit". American Journal of Critical Care. 2014; 13(2): $1-7$

[13] Novita Children's Services. Augmentative \& Alternative Communication [Internet]. South Australia; 2016 [cited 2016 Jan 20 ]. Available from: http://www.novita.org.au/services/augmentative_and_alternative_communication/

[14] Wang Y, Li H, Zou H, Li Y. Analysis of Complaints from Patients During Mechanical Ventilation After Cardiac Surgery: A Retrospective Study. Journal of Cardiothoracic Vascular Anaesthesia. 2015 Aug; 29(4): 990-994

[15] Baumgarten M, Poulsen I. Patients' Experiences of Being Mechanically Ventilated in an ICU: A Qualitative Metasynthesis. Wiley Online Library. 2014 Nov; 29(2): 205-214

[16] Magnus VS, Turkington L. Communication Interaction in ICU-Patients \& Staff Experiences \& Perceptions. Intensive \& Critical Care in Nursing. 2006; 22(3): 167-180

[17] Rajan R. Development of a Communication Board to Identify Needs of Patients on Mechanical Ventilation Post Coronary Artery Bypass Grafting. Cognitive Discourses International Multidisciplinary Journal. 2013 July; 1(1): 210-212

[18] Happ MB, Garrett K, Thomas DD, Tate J, George E, Houze M et.al. Nurse-Patient Communication Interactions in the Intensive Care Unit. American Journal of Critical Care. 2011 March; 20(2): 28- 40

[19] Guttormson JL, Bremer KL, Jones RM. "Not Being Able to Talk was Horrid": A Descriptive, Correlational Study of Communication during Mechanical Ventilation. Intensive and Critical Care Nursing. 2015Jun; 31(3): 179-186

[20] Flinterud SI, Andershed B. Transitions in the Communication Experiences of Tracheostomised Patients in Intensive Care: A Qualitative Descriptive Study. Journal of Clinical Nursing. 2015 Aug; 24 (15-16): 2295-2304 